\title{
Regulation of mouse epididymal epithelium in vitro by androgens, temperature and fibroblasts
}

\author{
R. Carballada and P. M. Saling \\ Departments of Obstetrics and Gynecology and Cell Biology, Duke University Medical Center, Durham, \\ NC 27710, USA
}

\begin{abstract}
The epididymal epithelium provides the microenvironment for sperm maturation. However, the molecular basis of epididymal function is still poorly understood because of the limitations of in vivo systems. For this reason, we have developed an in vitro culture system for mouse epididymal epithelial cells. Cells were purified by enzymatic digestion and centrifugation through a Percoll gradient, and plated on inserts coated with a replacement basement membrane. Cultured cells maintained ultrastructural and immunocytochemical features of epithelia, but did not retain the androgen responsiveness of epididymal cells (as judged by androgen receptor detection and secretion of specific markers) unless cocultured with fibroblasts. The androgen receptor was detected in the nuclei of epididymal epithelial cells only when grown with epididymal fibroblasts in the subjacent chamber. Moreover, specific epididymal secretory proteins were secreted only when epithelial cells were cultured in the presence of both androgens and fibroblasts at $32^{\circ} \mathrm{C}$. These results highlight the importance of cell-cell interaction, as well as temperature regulation in the physiology of the epididymis. They also establish the existence of two independent pathways in the differentiation of these cells. The first, leading to the expression of epithelial characteristics, is fibroblast-independent, whereas the second, conferring tissue-specific features, depends upon coculture with fibroblasts.
\end{abstract}

\section{Introduction}

The epididymis is a convoluted tubule embedded in a connective tissue matrix. Embryologically, it is derived from the Wolffian duct and, in adult mammals, reaches considerable complexity from both an anatomical and functional point of view (Bedford, 1975; Hamilton, 1975; Cooper, 1986). The proximal epididymis plays an essential role in sperm maturation which is critical for the ability of the cell to fertilize an egg and is thought to be promoted by the interaction of spermatozoa with epididymal secretions (Orgebin-Crist et al., 1981; Bedford and Hoskins, 1990). In contrast, the main function of the distal epididymis is temperature regulated storage of mature spermatozoa (Bedford, 1978). Study of epididymal physiology may, therefore, provide clues to how spermatozoa achieve and maintain their fertilizing capacity.

Classic studies have shown a role for androgens in the regulation of the epididymis (Cameo and Blaquier, 1976; Brooks and Higgins, 1980; Tezon et al., 1985); however, it is often difficult to discriminate direct effects on the epididymis from those caused indirectly by an effect on testicular function. In addition, the distal epididymis is temperature regulated (Bedford, 1978; Esponda and Bedford, 1986; Pera et al., 1996), but limitations inherent in the in vivo system have not allowed examination of this feature for the proximal regions. The development of in vitro systems seems essential to improve our knowledge of epididymal physiology. Such an experimental system may also be useful in promoting the in vitro maturation of spermatozoa, which would enable investigation of the molecular mechanisms that underlie epididymal maturation (Moore and Hartman, 1986; Moore et al., 1992; Bongso and Trounson, 1996).

Many attempts have been made to culture epididymal cells, from the initial studies using organ culture (Orgebin-Crist $e t$ al., 1987) to the culture of isolated epithelial cells (Kierszenbaum et al., 1981; Cooper et al., 1989; Byers et al., 1992). Rat (Byers et al., 1985; Cooper et al., 1989; Finaz et al., 1991) and human (Cooper et al., 1990; Huang et al., 1992; Moore et al., 1992; Raczek et al., 1995) epididymal epithelial cells grow in culture and form confluent monolayers. The cells keep their structural features, including a well developed Golgi apparatus, and maintain their polarity, endocytotic activity and junctional relationships (Djakiew et al., 1984; Cooper et al., 1989; Byers et al., 1992). The cells secrete several specific products (alkaline and acid phosphatases, $\mathrm{N}$-acetylglucosaminidase and secretory proteins; Kierszenbaum et al., 1981; Smith et al., 1986; Yeung et al., 1989; Cooper et al., 1990) and metabolize testosterone to the active metabolite, dihydrotestosterone (Brown et al., 1983; Amann et al., 1987; Raczek et al., 1994).

A major obstacle to the study of purified epithelial cells, however, is their tendency to lose hormone responsiveness (Cunha et al., 1985). Prostatic epithelial cells, immortalized by transfecting them with a plasmid containing SV40 large T antigen, display very low expression of the androgen receptor gene (Rundlett et al, 1992). Moreover, purified prostatic epithelial cells maintained in culture fail to express an 


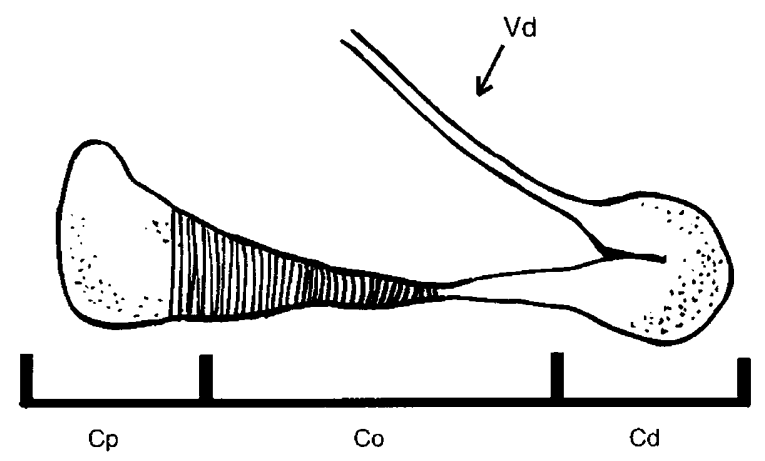

Fig. 1. Schematic representation of the mouse epididymis, with the shaded area indicating the regions used for cell culture. Cp: caput; Co: corpus; Cd: cauda; Vd: vas deferens.

androgen-dependent prostate specific binding protein (Chang and Chung, 1989), yet prostate explants that contain epithelial cells plus fibroblasts respond to androgens by secreting specific markers (Martikainen et al., 1987). Among the studies made thus far on epididymal epithelial cell culture, Raczek et al. (1994) failed to find any androgen dependence of cell height in human epididymal cultures that consisted solely of principal cells. In the few cases in which androgen responsiveness has been shown (Moore et al., 1986; Moore and Hartman, 1986; Smith et al., 1986; Bongso and Trounson, 1996), the authors cultured everted epididymal epithelia that contained more than one cell layer, so it is very likely that peritubular myoid cells were also present.

We have developed an in vitro culture system for the proximal regions of the mouse epididymis. We have used this system to determine some of the factors that regulate epithelial cell function in vitro as indicative of the mechanisms that operate in vivo. We show that both temperature and androgens regulate protein secretion by epididymal cells and that the androgen responsiveness of the epididymal epithelium depends upon coculture with the epididymal fibroblasts.

\section{Materials and Methods}

\section{Purification and culture of epithelial cells}

For each experiment, epididymides were obtained from ten 1-month-old Swiss mice (Harlan Sprague-Dawley, Indianapolis, IN). Mice were killed using $\mathrm{CO}_{2}$ and the epididymal regions to be cultured (Fig. I) were isolated in medium RPMI-1640 (Gibco BRL, Grand Island, NY). The tissue was incubated at $37^{\circ} \mathrm{C}$ in a tube rotator for $20 \mathrm{~min}$ in PBS containing trypsin $\left(2.5 \mathrm{mg} \mathrm{ml}^{-1}\right)$ and EDTA $(1 \% \mathrm{w} / \mathrm{v})$. After washing the preparation three times with RPMI-1640 supplemented with $5 \%$ fetal bovine serum (FBS), tubules (settled by gravity) were added to a dissociation solution consisting of dispase ( $25 \mathrm{U} \mathrm{ml}^{-1}$; Collaborative Research, Bedford, MA) and collagenase (1.5 $\mathrm{U} \mathrm{ml}^{1-}$; Sigma, St Louis, MO) in RPMI-1640 with $5 \%$ FBS. After incubation at $37^{\circ} \mathrm{C}$ in a tube rotator for $30 \mathrm{~min}$, the undigested tissue was allowed to settle and the supernatant containing free cells centrifuged at $200 \mathrm{~g}$ for $5 \mathrm{~min}$. The washed cells were resuspended in $1 \mathrm{mI}$ RPMI containing $5 \%$ FBS and fractionated in a discontinuous Percoll gradient prepared as described by Finaz et al. (1991). For each fraction, density was estimated using density marker beads (Pharmacia, Uppsala) and cell viability assessed by Trypan blue exclusion. The cell types present were estimated by the use of specific fluorochrome conjugated lectins. The lectins used were Ulex europaeus agglutinin conjugated to rhodamine (UEA-I-TRITC) and Bandeiraea simplicifolia conjugated to fluorescein (BS-IFITC) (Sigma). These lectins have been used previously to distinguish the different cell types in the epididymis (Burkett et al., 1987a, b). The layers enriched in principal cells were pooled and plated in culture medium. The medium (referred to as s-RPMI) was RPMI-1640 medium in which D-valine had replaced L-valine to discourage fibroblast growth (OrgebinCrist et al., 1984; Cooper et al., 1989) supplemented as described by Moore et al. (1986). When indicated, the medium also contained $200 \mathrm{nmol}$ testosterone $\mathrm{I}^{-1}$ and $1 \mu \mathrm{mol}$ dihydrotestosterone $\mathrm{I}^{-1}$. Cultures were maintained in $0.3 \mathrm{~cm}^{2}$ inserts (Collaborative Research, Bedford, MA), freshly coated with a thin layer of Matrigel (Collaborative Research) diluted 1:7 (Byers et al., 1992) in 24-well tissue culture plates. A volume of $0.25 \mathrm{ml}$ was used in the upper cell-containing chamber, and $0.5 \mathrm{ml}$ in the lower chamber. In experiments examining the effect of coculture with fibroblasts, the latter were confined to the lower chamber. Epithelial cells were plated at $0.3-0.6 \times 10^{6}$ cells $\mathrm{cm}^{-2}$ (low density) or $0.6-1.0 \times 10^{6}$ cells $\mathrm{cm}^{-2}$ (high density). The plates were cultured in $5 \% \mathrm{CO}_{2}$ at $37^{\circ} \mathrm{C}$ or at $32^{\circ} \mathrm{C}$. After 2 days, a serum-free defined medium was used (SFDM: s-RPMI in which FBS was replaced by $100 \mathrm{nmol}$ epidermal growth factor (EGF) $l^{-1}$ ). Thereafter, the medium was changed every 2 days. In experiments involving the recovery of proteins from supernatants, SFDM was supplemented with $1 \mathrm{mg} \mathrm{BSA} \mathrm{ml}{ }^{-1}$.

\section{Isolation and culture of fibroblasts}

Epididymal tubules were subjected to a $30 \mathrm{~min}$ digestion in $1.2 \mathrm{U}$ collagenase $\mathrm{ml}^{-1}$ and $10 \mathrm{U}$ dispase $\mathrm{ml}^{-1}$. Tissue fragments were allowed to settle by gravity, washed and plated in

Fig. 2. Ultrastructure of cultured epididymal epithelial cells. Cells were cultured for 4 days prior to fixation. (a) General view of the epithelial monolayer. The cell density at plating was $10^{6}$ cells $\mathrm{cm}^{-2}$. There are numerous apical microvilli in the luminal border of the cells and several organelles and vacuoli in the cytoplasm. Nuclei $(N)$ are rounded and mainly located in the basal pole. Scale bar represents $2 \mu \mathrm{m}$. (b) Detail of a cell showing a well developed Golgi apparatus $(\mathrm{G})$ close to the nucleus (N) and a lysosome granule (L). Scale bar represents $0.5 \mu \mathrm{m}$. (c) Detail of the apical border of the cultured cells. Below the microvilli $(\mathrm{mv})$ there are some vesicles (arrowheads). Accumulation of mitochondria (M) can also be seen. Scale bar represents $1 \mu \mathrm{m}$. (d) Basal pole of the cultured cells. The filter can be seen in the right corner at the bottom. Beneath the nucleus there are mitochondria $(\mathrm{M})$ and some vesicles (arrowheads). Scale bar represents $I \mu \mathrm{m}$. (e) General view of the epithelial monolayer. The cell density at plating was $0.5 \times 10^{\circ}$ cells $\mathrm{cm}^{-2}$. The cells are flattened and display scarce and shorter microvilli when compared with those plated at higher densities (see (a)). N, nucleus. Scale bar represents $2 \mu \mathrm{m}$. 

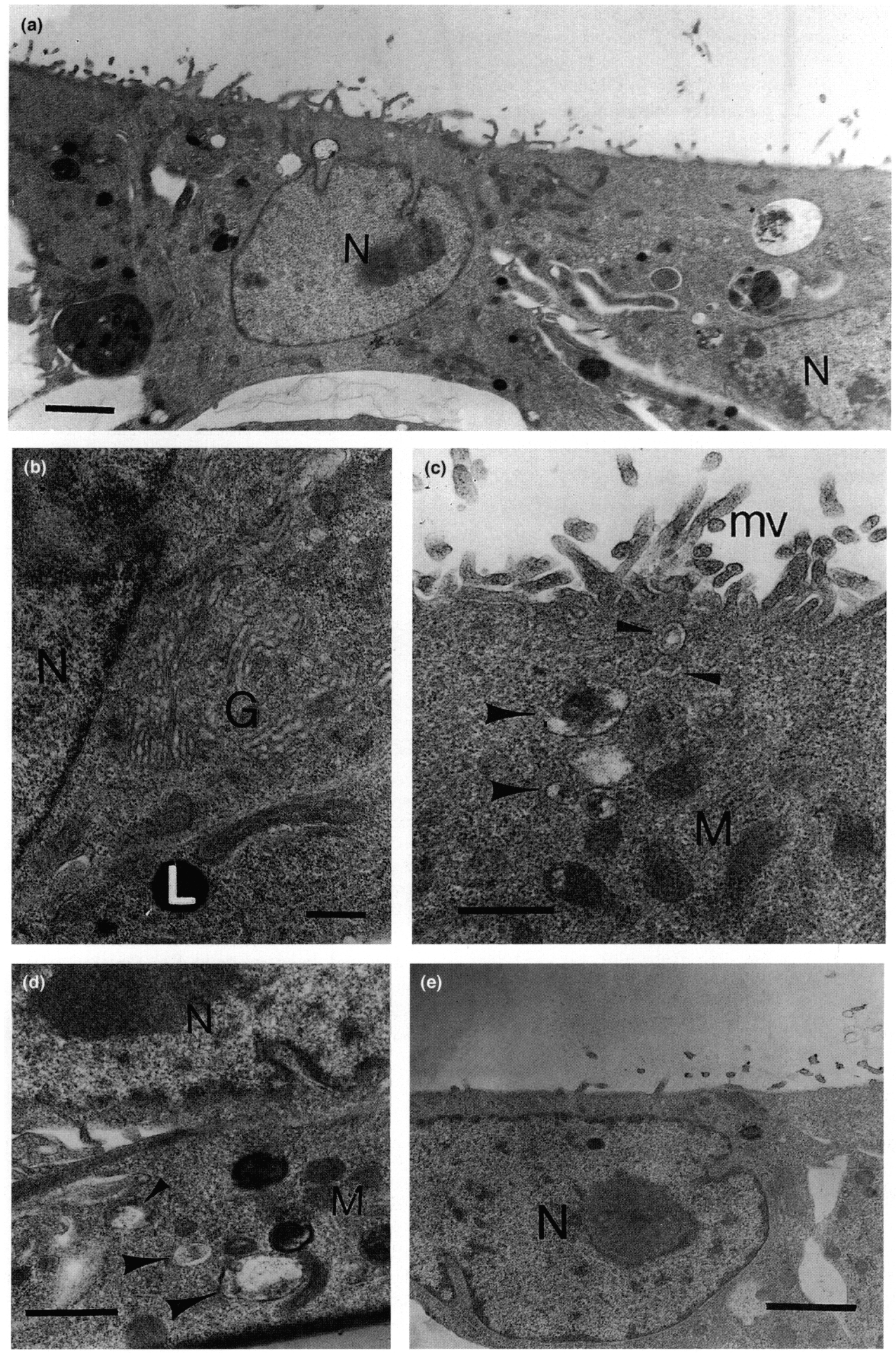

Fig. 2. 
culture medium (s-RPMI in which D-valine was substituted for L-valine). Culture was performed using 24-well Costar tissue culture plates, in $5 \% \mathrm{CO}_{2}$ at $37^{\circ} \mathrm{C}$. Under such conditions, a mixed population of cells plated and grew. On day 2, most of the cells were epithelial, but as the culture progressed, they were replaced by fibroblast-like cells, which had completely overgrown the epithelial cells by day 10. After this, they could be maintained in culture for at least a further $1-2$ weeks in a serum-free defined medium (f-SFDM). f-SFDM is f-RPMI in which FBS has been substituted by 3 nmol bFGF $1^{-1}$. For coculture experiments, the epithelial cells were isolated as described above and plated in inserts that were placed in the wells in which the fibroblast-like cells were growing. In some experiments, rabbit endothelial vascular cells (REVC) were used as controls, and cultured similarly to epididymal fibroblasts

\section{Electron microscopy}

Inserts containing the cells were washed in PBS and fixed for $1 \mathrm{~h}$ with $1 \%$ glutaraldehyde in $0.125 \mathrm{~mol}$ cacodylate buffer $\mathrm{l}^{-\mathrm{r}}$ containing $1 \%(\mathrm{w} / \mathrm{v})$ tannic acid. Cells were then washed in cacodylate buffer, and the filter bearing the fixed cells was cut out and washed in distilled water. After dehydration through graded alcohols and infiltration with Spurr resin (Polysciences, Warrington, PA), the filter was cut into strips and embedded. Ultrathin silver-gold sections were stained with lead citrate and uranyl acetate, and examined in a Phillips 301 electron microscope.

\section{Defection of cytokeratin and uvomorulin}

Cells were fixed on the inserts with $2 \%(\mathrm{w} / \mathrm{v})$ $p$-formaldehyde in PBS ( $\mathrm{pH}$ 7.5) for $10 \mathrm{~min}$ and incubated for $30 \mathrm{~min}$ in $20 \mathrm{mmol}$ glycine $1^{-1}$ in PBS (pH 7.5) to block free aldehyde groups. Cells were permeabilized for $30 \mathrm{~min}$ in a solution of PBS containing $0.5 \%(\mathrm{v} / \mathrm{v})$ Triton $\mathrm{X}-100$ and processed for indirect immunofluorescence following standard procedures. The primary antibody was mouse anti-pan cytokeratin $(\mathrm{I}: 20)$ or rat anti-uvomorulin (I:100) in PBS- $1 \%(\mathrm{w} / \mathrm{v})$ BSA. The second antibody solutions contained anti-mouse IgG conjugated to TRITC and anti-rat IgG conjugated to fluorescein isothiocyanate (FITC), respectively, diluted in $1 \%$ BSA in PBS. These antibodies were purchased from Sigma. Stained cells were mounted on slides with Gelvatol (Monsanto, St Louis, MO) and examined using a Zeiss microscope equipped with epifluorescence and appropriate filters. Controls, including irrelevant monoclonal antibodies as primary antibody, were also conducted.

\section{$\left.P^{3} H\right]$ methyl thymidine labelling experiments}

$\left[{ }^{3} \mathrm{H}\right]$ methyl thymidine $(2 \mu \mathrm{Ci}$; ICN, Costa Mesa, CA) was added to the lower culture chamber at plating (day 0 ) or on days $1,2,3,4,5$ and 6 . After $24 \mathrm{~h}$, epithelial cells on the inserts were rinsed in PBS, fixed for $1 \mathrm{~min}$ in methanol:acetic acid (3:I; v:v), and air-dried. Cells were coated with a photographic emulsion (NTB-2, Kodak, Rochester, NY) and exposed for $48 \mathrm{~h}$ at $4^{\circ} \mathrm{C}$. The emulsion was developed in D-19 (1:2 in distilled
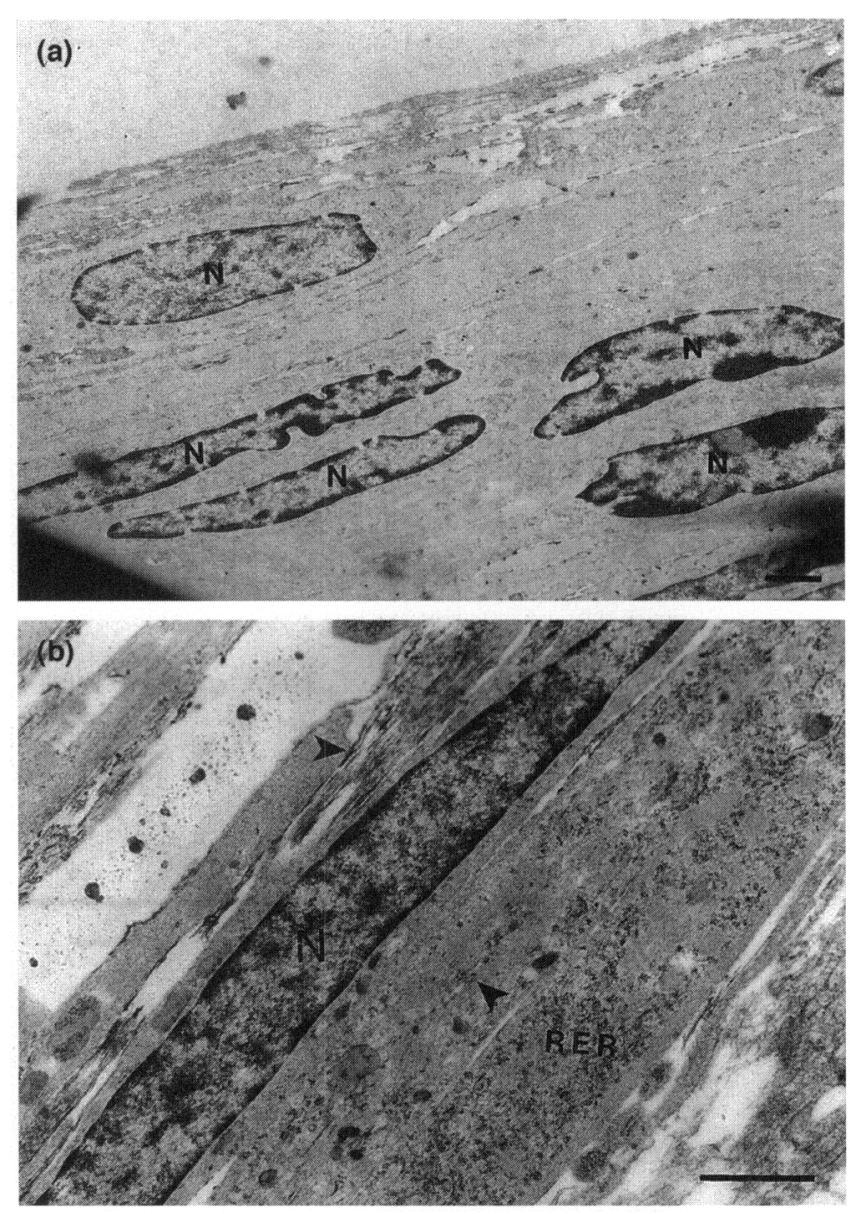

Fig. 3. Ultrastructure of cultured epididymal fibroblast-like cells. Cells were cultured for 12 days prior to fixation. (a) General view of the fibroblasts, which grow in several layers and have elongated nuclei (N). (b) High magnification of an epididymal fibroblast, showing a well developed rough endoplasmic reticulum (RER) and bundles of fibrils (arrowheads). N, nucleus. Scale bars represent $2 \mu \mathrm{m}$.

water) and fixed in rapid fix (Kodak). After staining with toluidine blue, the mitotic index (percentage of labelled nuclei) was estimated by counting more than 500 cells per slide for each time interval and for each of the conditions tested.

\section{Localization of androgen receptor}

Cells were fixed and permeabilized as described and then incubated for $3 \mathrm{~h}$ in a blocking solution consisting of PBS with $0.05 \%(\mathrm{w} / \mathrm{v})$ sodium azide, $5 \%(\mathrm{w} / \mathrm{v}) \mathrm{BSA}$ and $0.4 \%(\mathrm{v} / \mathrm{v})$ Triton $X-100$. After washing in PBS with $1 \%$ BSA, a solution of rabbit anti-human androgen receptor (1:100; Affinity Bioreagents, Meshanic Station, NJ) in PBS-1\% BSA-0.4\% Triton X-100 was added and incubated overnight at $4^{\circ} \mathrm{C}$. Reactivity was detected using biotinylated anti-rabbit IgG (1:200 in PBS-1\% BSA; Sigma, St. Louis, MO) and anti-biotin antibody conjugated to horseradish peroxidase (HRP) (1:200 in PBS-1\% BSA; Sigma), followed by incubation in a substrate solution containing $0.75 \mathrm{mg}$ diaminobenzidine $\mathrm{ml}^{-1}, 0.09 \mu \mathrm{H}_{2} \mathrm{O}_{2}(30 \%) \mathrm{ml}^{-1}$ and $0.03 \%(\mathrm{w} / \mathrm{v}) \mathrm{NiCl}_{2}$ in Tris buffer $\left(50 \mathrm{mmol} \mathrm{l}^{-1}\right.$; $\mathrm{pH} \mathrm{7.5)}$. 

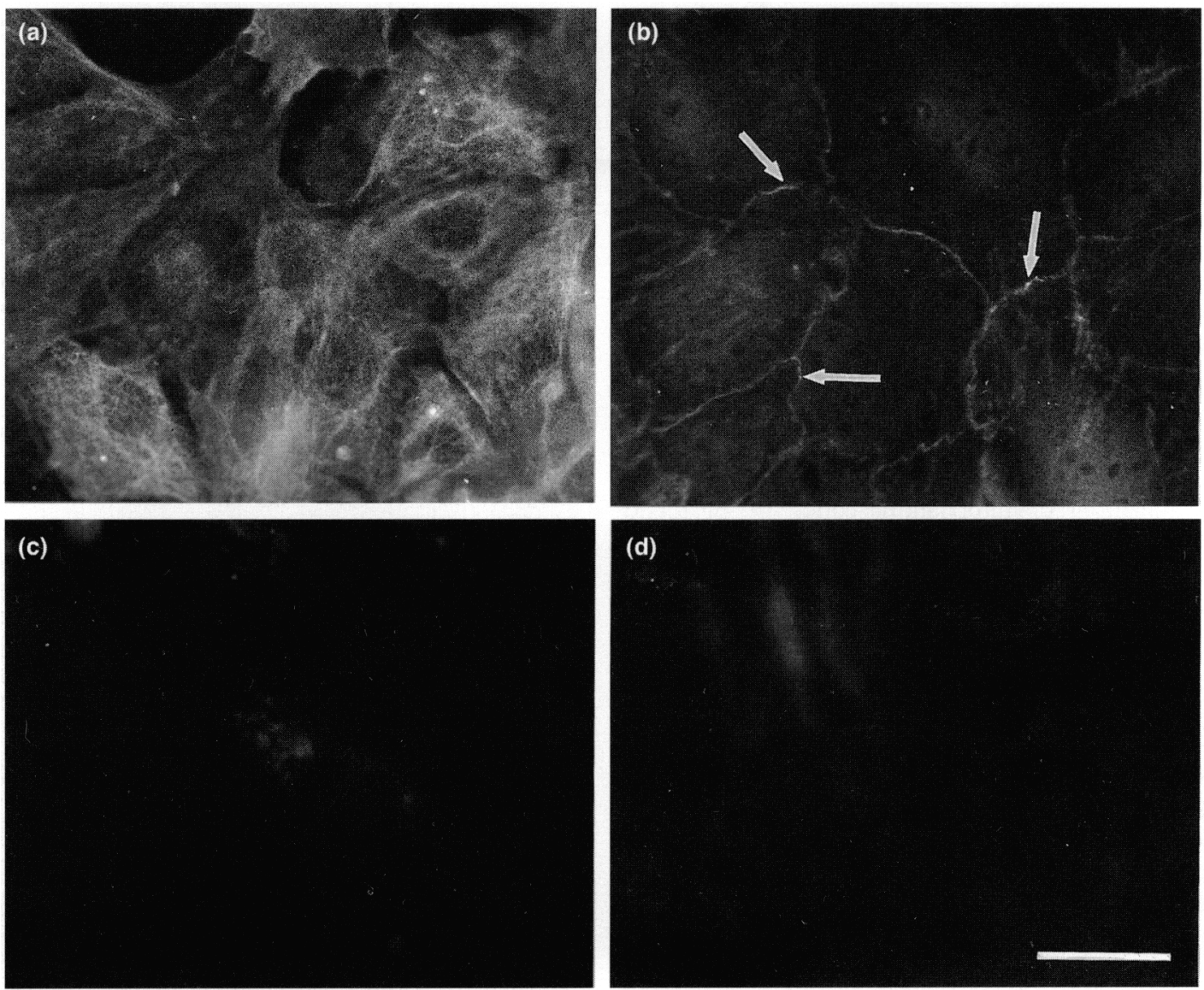

Fig. 4. Detection of cytokeratin and uvomorulin in epididymal cells, fixed 3 days after plating. Cytokeratin forms a network in the cytoplasm of the epithelial cells (a), while uvomorulin is restricted to cell borders (arrows), being part of the junctional complexes between cells (b). Controls, including an irrelevant monoclonal as primary antibody, were negative for both cytokeratin (c) and uvomorulin. Fibroblasts were also negative for both markers. Fibroblasts stained with the anti-uvomorulin antibody are shown in (d). Scale bar represents $20 \mu \mathrm{m}$.

Inserts were then washed in distilled water, mounted on slides and examined.

\section{SDS-PAGE, western blot and lectin staining in nitrocellulose filters}

Supernatants from cultured cells were collected every 2 days, clarified by centrifugation (10000 $g$ for $5 \mathrm{~min}$ ), and the proteins precipitated with trichloroacetic acid (TCA) and recovered in sample buffer. For SDS-PAGE, $50 \mu \mathrm{g}$ of protcin (corresponding to half of the total protein recovered) were used (Laemmli, 1970) and the proteins were transferred to $0.2 \mu \mathrm{m}$ pore nitrocellulose filters (Schleicher and Schucll, Keene, $\mathrm{NH}$ ) following standard procedures. The filters were blocked with $5 \%$ non-fat dried milk in washing buffer $(50 \mathrm{mmol}$ Tris $\mathrm{I}^{-1}, \quad 150 \mathrm{mmol} \mathrm{NaCl} 1^{-1}, 0.2 \%(\mathrm{w} / \mathrm{v})$ gelatin, $0.05 \%(\mathrm{v} / \mathrm{v})$ Tween-20) overnight at $4^{\circ} \mathrm{C}$ and then used for western blots. The primary antibody used was a guinea-pig serum that recognizes the protein CP 27 (Flickinger et al., 1988), diluted 1:1000 in washing buffer. Filters were incubated sequentially with biotinylated anti-guinea-pig IgG (1:4000 in washing buffer) and anti-biotin-HRP (1:4000 in washing buffer) and positive staining was detected using an enhanced chemoluminiscent substrate (ECL, Amersham, Little Chantlon). WGA- binding sites were detected with commercial WGA conjugated to biotin (Genzyme, Cambridge, MA). Briefly, blocking of non-specific sites was carried out for $\mathrm{I} h$ in a solution containing $0.5 \mathrm{~mol} \mathrm{NaCl} 1^{-1}, 20 \mathrm{mmol}$ Tris $1^{-1}, 10 \mathrm{mmol} \mathrm{CaCl}_{2} \mathrm{l}^{-1}$, $10 \mathrm{mmol} \mathrm{MgCl}_{2} \mathrm{I}^{-1}, 10 \mathrm{mmol} \mathrm{MnCl}_{2} \mathrm{I}^{-1}$ and $2 \%(\mathrm{w} / \mathrm{v})$ gelatin ( $\mathrm{pH}$ 7.4) and then $4 \mu \mathrm{g}$ of biotinylated lectin $\mathrm{ml}^{-1}$ was added and incubation progressed for $2 \mathrm{~h}$. The proteins recognized were revealed by use of an anti-biotin-HRP antibody (1:5000 in washing buffer), followed by ECL.

\section{Dot blot and densitometry}

Supernatants recovered at 2 day intervals were clarified as described above and blotted onto nitrocellulose filters using a Bio-Dot Microfiltration Apparatus (Bio-Rad, Richmond, CA). Filters were then used for immunoblot with anti-CP 27 as described above. The exposed films were scanned using a OneScanner (Macintosh, Apple Computer Inc, Cupertino, CA) and analysed using NIH-Image software. Analysis of variance (ANOVA) followed by Duncan's test was used to examine statistical differences among the different treatments. 


\section{Results}

Characterization of the cultured epithelial and fibroblast-like cells from the epididymis

The epithelial cells, regardless of the presence or absence of fibroblasts or androgens, plated and grew, reaching confluence by day 3-5. Electron microscopy confirmed that the cells formed a monolayer and displayed a marked polarity with apical microvilli and basal nuclei (Fig. 2a). Junctional complexes were observed, especially in the apical pole. The endoplasmic reticulum and Golgi apparatus were well developed (Fig. 2b) and there were vesicles of several sizes that may have been multivesicular bodies, secretory granules or endocytotic vesicles. These vesicles were especially abundant in the apical pole, in which accumulations of mitochondria could also be found (Fig. 2c). At the basal pole, some vesicles and mitochondria could also be distinguished (Fig. 2d). Polarity was dependent on cell density, with a flattened shape and fewer microvilli at lower density (Fig. 2e). Fibroblast-like cells presented a markedly different morphology. Electron micrographs confirmed that they neither formed monolayers nor displayed signs of polarity (Fig. 3a). They had elongated central nuclei, abundant rough endoplasmic reticulum and relatively few organelles. Cytoplasmic fibrils could be seen in some areas (Fig. 3b). For further characterization of these populations, the epithelial cell markers cytokeratin and uvomorulin were used. Epididymal epithelial cell preparations stained positively (Fig $4 \mathrm{a}, \mathrm{b}$ ) and specifically (Fig 4c) for both markers, whereas fibroblast-like cells were negative (uvomorulin is shown in Fig. $4 \mathrm{~d}$; data for cytokeratin are not shown).

\section{Dynamics of epithetial cell growth in culture}

The evolution of mitotic indices was examined by labelling with $\left[{ }^{3} \mathrm{H}\right]$ methyl thymidine at different time points and analysing the parameters of cell density, androgen dependence, fibroblast coculture and temperature for effects on the dynamics of cell growth. Temperature was the only factor that displayed a significant effect (Fig. 5). The mitotic indices at $37^{\circ} \mathrm{C}$ peaked on day 3 while, at $32^{\circ} \mathrm{C}$, the peak was not reached until day 4 (Fig. 5a). Temperature also had an effect on cell viability. At $37^{\circ} \mathrm{C}$, the peak of growth occurred rapidly and, once proliferation stopped, the cells did not survive. At $32^{\circ} \mathrm{C}$, however, although growth occurred at a slower rate, cells survived even when they were no longer proliferating (Fig. 5, compare (a) with (b)). Aside from temperature, the other factors examined (cell density, androgens and coculture with fibroblasts) did not detectably influence cell proliferation.

\section{Localization of androgen receptor}

Under our culture conditions, androgen receptors were detected in the nuclei of fibroblasts, but only in those cultured in the presence of androgens (Fig. 6a, b). They were also present in the nuclei of epithelial cells cocultured with fibroblasts in the presence of androgens, regardless of the temperature (Fig. $6 \mathrm{c}, \mathrm{d}$ ). Although present initially, the androgen receptor was undetectable by day 3 when the epithelial cells (a)

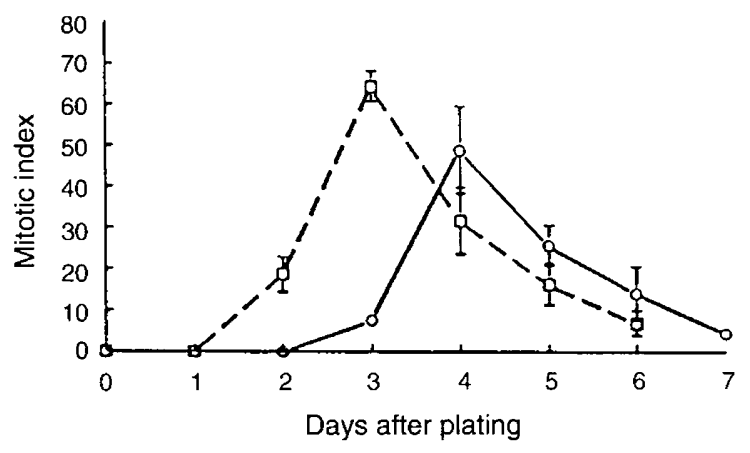

(b)

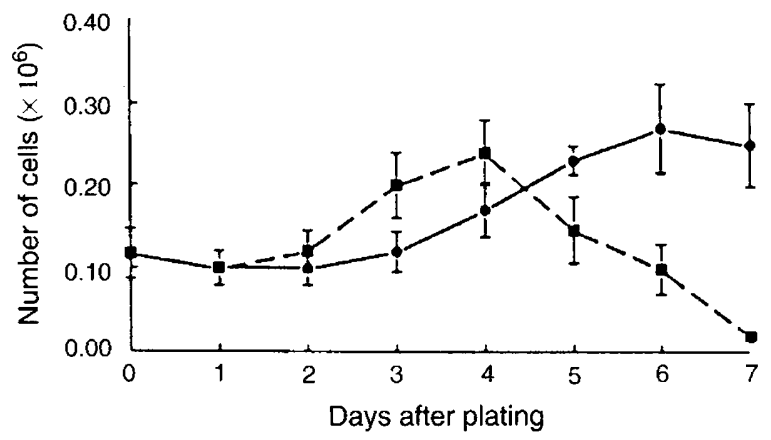

Fig. 5. Growth curves of epididymal epithelial cells in vitro. Cells were cultured at $32^{\circ} \mathrm{C}(\bigcirc, \boldsymbol{O})$ or $37^{\circ} \mathrm{C}(\square, \mathbf{\square})$, in the presence of fibroblasts and androgens, and labelled with $\left[{ }^{3} \mathrm{H}\right]$ thymidine for $24 \mathrm{~h}$. Both the mitotic indices (a) and number of cells (b) were plotted as a function of time (mean $\pm \mathrm{SD}$ ). At least three experiments were conducted for each time point.

were cultured with fibroblasts but in the absence of androgens (Fig. 6e), or with androgens in the absence of fibroblasts (Fig. 6f).

\section{Protein secretion by the cultured epithetial cells}

The expression of a specific protein marker such as CP 27 was analysed (Figs 7 and 8). CP 27 was detected readily in supernatants recovered after incubation of whole epididymal tissue (Fig. 7, lane f) and in supernatants from cells that had been cultured in the presence of androgens and fibroblasts (Fig. 7 , lanes $d$ and e). When the epithelial cells were not cocultured with fibroblasts (Fig. 7, lane b) or when coculture occurred in the absence of androgens (Fig. 7, lane c), CP 27 was substantially reduced. CP 27 was also undetectable in supernatants from cultured fibroblasts (Fig. 7, lane a). The secretion of CP 27 by cultured cells varied with time (Fig. 8). During the first 2 days, CP 27 was present in all cultures regardless of temperature, androgen or fibroblast culture conditions. Since the CP 27 signal was maximal in supernatants collected after the first 2 days of culture, this was considered to represent $100 \%$ secretion and the amounts of CP 27 present in the supernatants on successive days were normalized as a percentage of this value. This analysis revealed that CP 27 production and secretion, or both, decreased abruptly on days 3-4 unless the cells were cultured at $32^{\circ} \mathrm{C}$ with fibroblasts and androgens. In this case, 

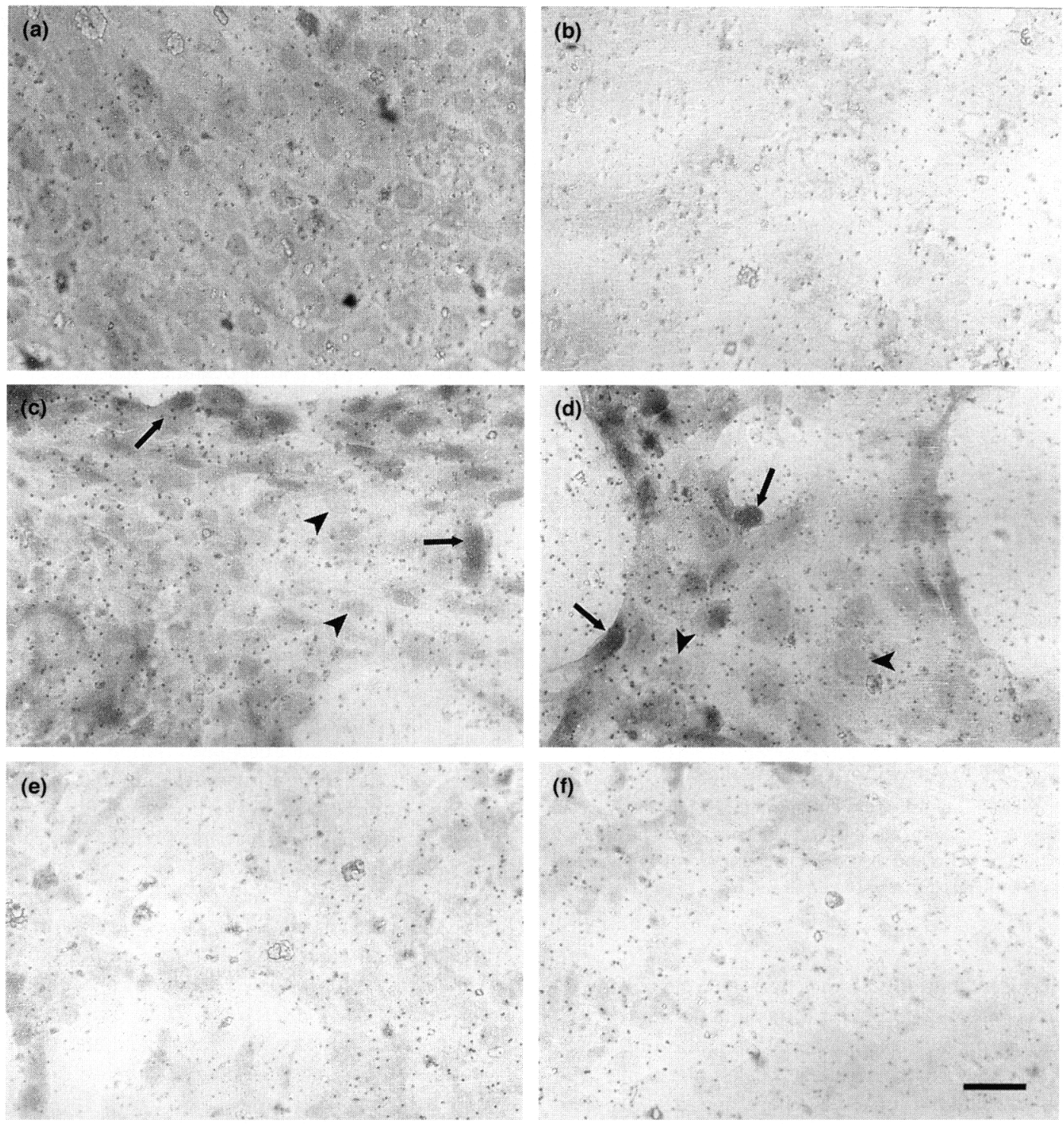

Fig. 6. Localization of the androgen receptor in cultured epididymal celis. (a, b) Cultured fibroblasts, fixed 12 days after plating. The androgen receptor was detected in the nuclei of fibroblasts cultured in the presence (a), but not in the absence (b), of androgens. ( $c-f$ ) Epithelial cells, fixed 4 days after plating. Epithelial cells, stained positively when cultured in the presence of androgens and fibroblasts, regardless of the temperature of the culture, $\left(\mathrm{c}: 37^{\circ} \mathrm{C} ; \mathrm{d}: 32^{\circ} \mathrm{C}\right.$ ). The intensity of staining varied, being more intense in some nuclei (arrows) than in others (arrowheads). However, androgen receptors were not detected in cells cocultured with fibroblasts at $32^{\circ} \mathrm{C}$ but in absence of androgens (e) or cells cultured at $32^{\circ} \mathrm{C}$ with androgens but in absence of fibroblasts $(\mathrm{f})$. The speckled pattern seen in all figures is due to the pores of the filter that supported the cells. Scale bar represents $20 \mu \mathrm{m}$.

the amount of $\mathrm{CP} 27$ present in the supernatants was about $70 \%$ of the maximum and differences between androgen and non-androgen conditions were clear (Figs 7 and 8). It is noteworthy that coculture with epididymal fibroblast-like cells produced this effect on CP 27 secretion and a mesenchymal cell line, REVC, was ineffective (Fig. 8). After 5-6 days, the amount of CP 27 decreased in all cases and could not be detected in supernatants collected on day 8 .

Lectin blots were used to determine whether cultured epithelial cells secreted other tissue-specific markers such as the two WGA binding proteins GP-49 and GP-83 (Fig. 9). The results showed that the protein expression pattern of epididymal fluid in vivo (lane a) was preserved in vitro (lane d). Resembling the expression of CP 27, the expression of GP 49 and GP 83 required all three factors $\left(32^{\circ} \mathrm{C}\right.$, androgens and fibroblasts); culture at $37^{\circ} \mathrm{C}$ (lanes e, f) or at $32^{\circ} \mathrm{C}$ without androgens (lane c) or without fibroblasts (lane b) prevented detection of these proteins.

\section{Discussion}

The isolation and culture of epididymal epithelial cells allows detailed studies on the physiology of the epididymis. The 
a b C

d e

71

43

29

18

15
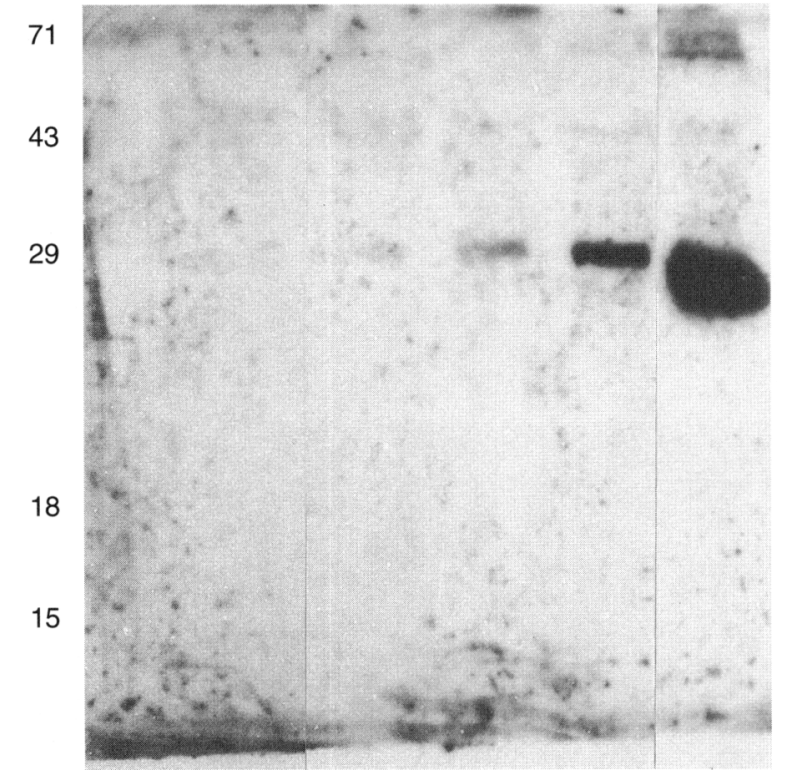

Fig. 7. Detection of protein CP 27 in culture supernatants, collected on day 4 of culture. Lanes represent supernatants collected from fibroblasts (a), epithelial cells (b-e) or whole epididymal tubules ( $\mathrm{f}$ ). Fibroblasts were cultured in the presence of androgens at $32^{\circ} \mathrm{C}$. Epithelial cells were plated at low (b-d; $0.4 \times 10^{6}$ cells $\mathrm{cm}^{-2}$ ) or high (e; $0.8 \times 10^{6}$ cells $\mathrm{cm}^{-2}$ ) density and cultured at $32^{\circ} \mathrm{C}$ in the presence $(d, e)$ or absence (c) of androgens. Epithelial cells providing supernatants for lanes $\mathrm{c}, \mathrm{d}$ and e had also been cocultured with fibroblasts. Migration of the molecular mass standards $\left(\times 10^{-3}\right)$ is indicated on the left.

epithelial cells used in these studies were purified from the distal caput and proximal corpus of the epididymis since these regions play an important role in sperm maturation (OrgebinCrist et al., 1981; Bedford and Hoskins, 1990; Soler et al., 1994) and are easily digested using collagenase and dispase. Onemonth-old mice were used because, in young animals, fewer spermatozoa are present in the tubules and the connective tissue is more easily digested, enabling consistent recovery of larger numbers of cells than from older mice. The cultured epithelial cells exhibited $<5 \%$ contamination with other cell types, as judged by staining with lectins and cytokeratin. Regardless of the coculture with fibroblasts, these epithelial cells behaved as predicted; they formed confluent monolayers and retained ultrastructural and cytochemical features of epithelial cells. The most typical feature, marked polarity (mainly measured by cell height and development of apical structures, such as microvilli) was maintained and, importantly, it was correlated with cell density. Cells at low densities were flattened and had scarce microvilli, whereas at higher density they varied from cuboidal to columnar, although they never reached the height of the epithelium in vivo. They also displayed longer and more abundant microvilli. This effect on cell morphology has been reported by others (Byers et al. 1986) and suggests that intraepithelial paracrine factors play a role in maintaining a differentiated epithelial cell pattern. Finally, the cultured cells displayed positive staining for cytokeratin and uvomorulin, recognized markers of epithelial cells (Byers et al.,
1985, 1992; Finaz et al., 1991). These markers were present in the cells during the entire period of culture, regardless of the presence of androgens or fibroblasts.

Epididymal fibroblasts were isolated by taking advantage of the fact that these cells grow very well in vitro in a serum-rich medium. They overgrew the short-lived epithelial cells and, by day 10 , were present at $100 \%$ purity. However, it is important to state that in these studies the broadest definition of the term 'fibroblast' is used. In fact, it is likely that the fibroblastlike cells observed represent a mixed population since the epididymis contains peritubular myoid cells in addition to stromal cells. This fibroblast-like cell population showed a pattern of growth and appearance that is characteristic of all mesenchyme-derived cells when grown in culture. Their ultrastructural characteristics were also those of fibroblast-like cells (no signs of polarity, fibrils in the cytoplasm) and they secreted extracellular matrix. Neither of the epithelial markers examined (cytokeratin and uvomorulin) showed a positive reaction with this population.

The cultured epithelial cells were able to undergo mitosis in the culture conditions used. There was no effect of either fibroblasts or androgens in promoting cell growth, in contrast to the situation described in prostatic cells (Cunha et al., 1985; Chang and Chung, 1989; Rundlett et al., 1992). However, unlike the situation in the prostate, the mitotic index in the epididymal epithelium decreases during postnatal development and is virtually zero in the adult (Sun and Flickinger, 1982). In fact, the cultured cells in the present study stopped proliferating spontaneously. Of the parameters examined, only temperature affected the dynamics of epididymal epithelial cell growth.

The localization of the androgen receptor in the cultured cells was studied since this is one of the most conspicuous features of differentiated epididymal epithelium in vivo. Androgen receptors are localized in the nuclei of epithelial cells and also in the subjacent stromal cells (Sar et al., 1990); during embryonic development of the organ, androgen receptors are also detected in mesenchymal cells before their localization in epithelial cell nuclei (Cooke et al., 1991). The androgen receptor was detected in the nuclei of epididymal fibroblasts cultured in the presence of androgens. In epithelial cells, nuclear localization was lost after 3 days of culture unless the cells were cocultured with fibroblasts in the presence of androgens. Temperature did not affect this pattern, which is in agreement with previous reports (Regalado et al., 1993; Pera et al., 1996).

For examination of protein secretion, the first marker studied was CP 27. This protein is the most abundant protein in fluid from the mouse cauda epididymides and is produced and secreted in the distal caput and proximal corpus epididymides (Flickinger et al., 1988). CP 27 was detected in supernatants of epithelial cells regardless of the culture conditions during the first 2 days. This represents a lag period in which the cells still reflect in vivo conditions. From day 3, the content of CP 27 in the supernatants decreased unless the cells were cocultured with fibroblasts at $32^{\circ} \mathrm{C}$ in presence of androgens. Importantly, the effect of coculture was somehow specific to epididymal fibroblasts, since coculture of epididymal epithelial cells with other mesenchyme-derived cells (REVC) failed to restore androgen sensitivity. It is noteworthy that the secretion of $\mathrm{CP}$ 27 cannot be maintained for long periods; after a week of culture, it was undetectable even with optimal conditions. 

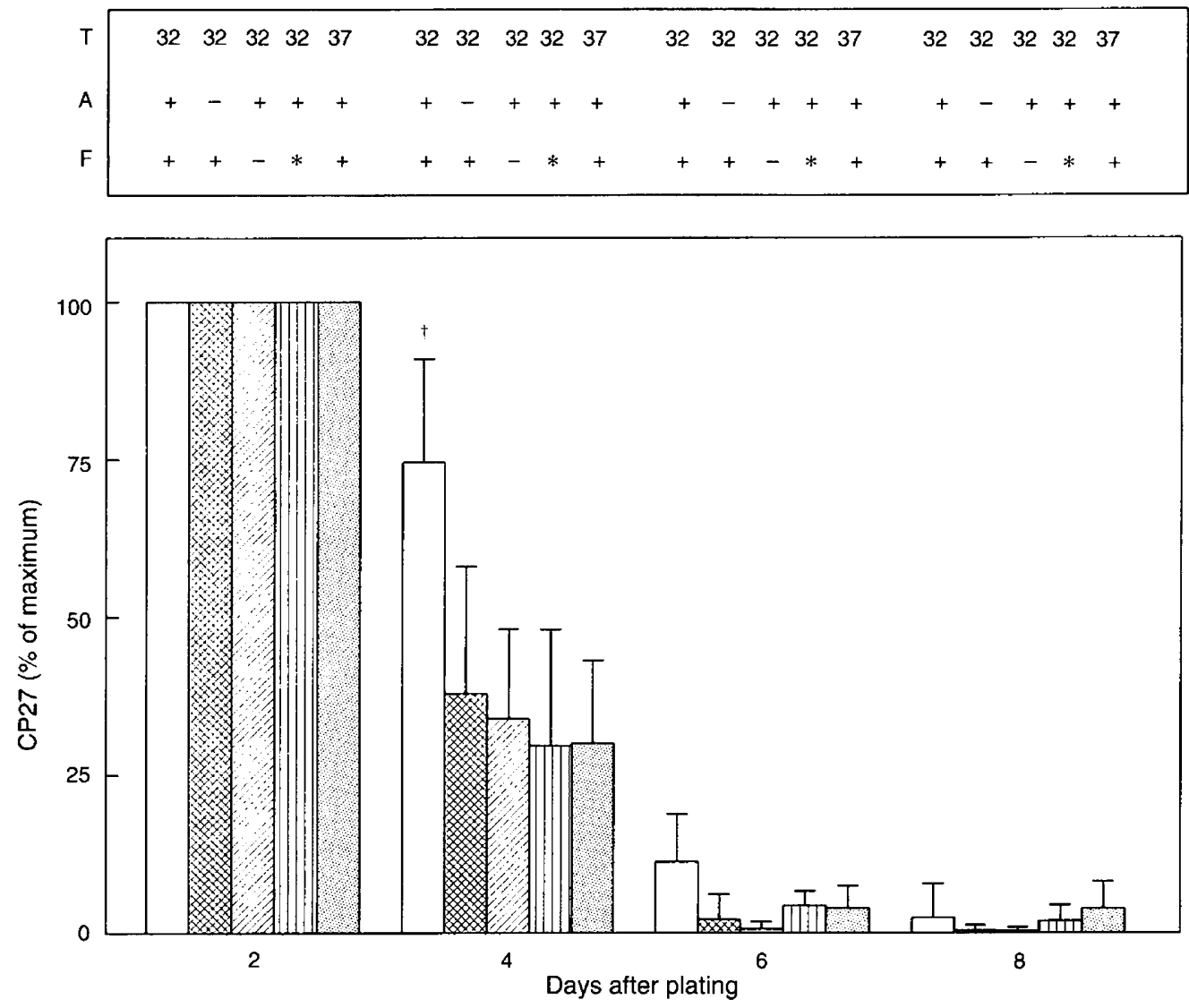

Fig. 8. Secretion of protein $C P 27$ as a function of time and culture conditions. CP 27 was quantified in the supernatants from the different cultures by densitometry. The quantities detected on day 2 were maximal for all samples; these values were considered $100 \%$ and used to normalize the other values measured. Data represent the mean $\pm \mathrm{SD}(n=5)$. T, temperature; A, androgens; $\mathrm{F}$, fibroblasts; ${ }^{*}$ rabbit endothelial vascular cells (REVC) were used instead of epididymal fibroblasts. ${ }^{\dagger}$ Significantly different $(P<0.05)$.

WGA staining was also used to evaluate protein secretion. Although not as specific as antibody detection, this probe has been used to define two glycoproteins, GP-49 and GP-83, which are androgen-dependent proteins secreted by the mouse corpus and cauda epididymides (Liu et al., 1992). GP-49 and GP-83 secretion paralleled the situation described above; only those epididymal epithelial cells cocultured with fibroblasts at $32^{\circ} \mathrm{C}$ in the presence of androgens displayed a pattern of secretion similar to that of the organ in vivo.

The results of the present study suggest that mesenchymederived cells in the epididymis play a key role in the maintenance of androgen responsiveness in the postnatal epithelium, supporting the suggestion of Cunha et al. (1985). This is not a characteristic of androgen regulation alone, but also occurs for oestrogen (Cooke et al., 1986). It has also been demonstrated that the culture of epithelial cells on feeder layers composed of stromal cells has beneficial effects regarding epithelial cell growth (Manin et al., 1992) and differentiation (Kedinger et al., 1987). With regard to a putative mechanism of action, the detection of larger amounts of secretory markers in epithelial cell supernatants after coculture cannot be explained on the basis of increased cell numbers, since the fibroblasts did not promote cell growth. Alternatively, it seems that fibroblasts may provide some signal to epithelial cells, enabling them to retain a differentiated pattern. This signal must be a soluble factor, since it can pass from the lower to the upper compartment. Swinnen et al. (1990) propose that soluble factors secreted by different cell types of mesenchymal origin modulate the androgen responsiveness of Sertoli cells in culture. Coculture of Sertoli cells with stromal or peritubular cells increases the secretion of some specific markers from the Sertoli cells, such as androgen-binding protein and transferrin (Verhoeven et al., 1992; Janecki and Steinberger, 1987; Thompson et al., 1995). Moreover, prostatic stromal cells and testicular peritubular myoid cells are effective in promoting such an effect, while footsole fibroblasts are not (Swinnen et al., 1990). The results of the present study are consistent with a similar mechanism of action.

Temperature was found to be a major factor controlling protein synthesis and secretion in the cultured epithelium, indicating that temperature regulates protein synthesis not only in the testis and distal portions of the epididymis (Esponda and Bedford, 1986; Bedford, 1991), but also in the proximal epididymis. Temperature effects do not appear to be mediated by androgens, and are probably also independent of fibroblast-secreted factors, since in the present study 


\begin{tabular}{|c|c|c|c|c|c|}
\hline 32 & 32 & 32 & 32 & 37 & 37 \\
\hline+ & + & - & + & - & + \\
\hline$+^{a}$ & - & + & + & + & + \\
\hline
\end{tabular}

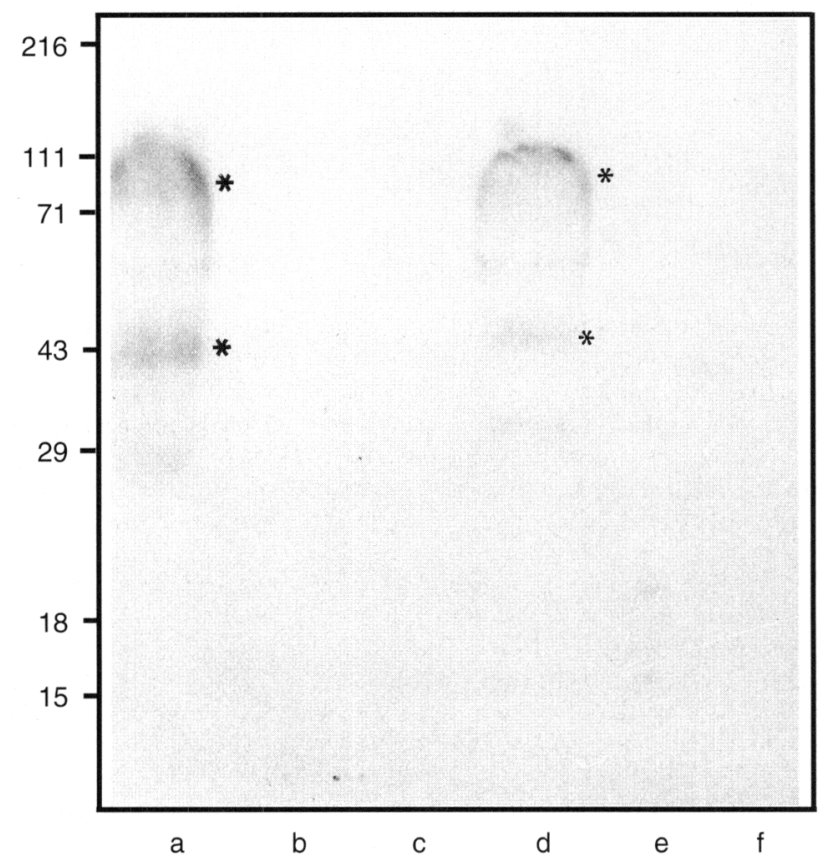

Fig. 9. Detection of WGA-binding glycoproteins in the supernatant of cultured epithelial cells. Lane a represents supernatant recovered from the incubation of whole epididymal tubules; lanes b-f represent supernatants collected from epithelial cells cultured under the conditions indicated $\left(\mathrm{T}\right.$, temperature. $\mathrm{A}$, androgens. $\mathrm{F}$, fibroblasts). ${ }^{\mathrm{a}}$, whole tissue containing fibroblast-like cells that had not been dissociated from the epithelium. The two major WGA-binding proteins, GP-83 and GP-49, are indicated by asterisks.

temperature affected protein secretion but not androgen receptor localization. This is in agreement with previous reports in rats (Regalado et al., 1993) and dogs (Pera et al., 1996).

In summary, three factors appear to be essential to maintain a differentiated state in cultured epididymal epithelial cells. Temperature and androgens appear to operate via independent pathways. Fibroblasts, however, appear to facilitate the androgen response of the epithelium. Collectively, the results of the present study suggest that fibroblasts do not play a role in the differentiation of these cells as epithelial, since they retain their epithelial pattern in the absence of fibroblasts. Indeed, some epithelial features, such as marked polarity, may be self-regulated. Fibroblast factors may act to refine the epithelial pattern by inducing tissue-specific protein secretion. The system described here may be a useful tool with which to undertake molecular studies on differential gene expression and the secretory activity of the epididymis, as well as to promote sperm maturation in vitro.

The authors are grateful to C. J. Flickinger, J. C. Herr and K. L. Klotz from the University of Virginia for providing the antisera against protein CP 27. They also thank J. M. Bedford (Cornell University, NY), T. G. Cooper (Institute of Reproductive Medicine, Münster,
Germany), C. Kirchhoff (IHF, Hamburg, Germany) and R. Ivell (IHF, Hamburg, Germany) for helpful suggestions that allowed them to improve the manuscript. This work was supported by NIH grant HD18201. R. Carballada is also grateful for support from the Andrew W. Mellon Foundation.

\section{References}

Amann RP, Marengo SR and Brown DV (1987) Steroidogenesis and testosterone metabolism in cultured principal cells from the ram epididymis Journal of Andrology 8 238-246

Bedford JM (1975) Maturation, transport and fate of spermatozoa in the epididymis. In Handbook of Physiology Vol. 5 Endocrinology pp 303-317 Eds RO Greep and EB Astwood. American Physiological Society, Washington

Bedford JM (1978) Influence of abdominal temperature on epididymal function in the rat and rabbit American Journal of Anatomy 52 509-522

Bedford JM (1991) Effects of elevated temperature on the epididymis and testis experimental studies. In Temperature and Environmental Effects on the Testis Ed. A Zorgniotti Advances in Experimental Medicine and Biology 286 19-32

Bedford JM and Hoskins DD (1990) The mammalian spermatozoon morphology, biochemistry and physiology. In Marshall's Physiology of Reproduction (4th Edn) Vol. 2 pp 379-568 Ed. GE Lamming. Churchill Livingston, London

Bongso A and Trounson A (1996) Evaluation of motility, fertilizing ability and embryonic development of murine epididymal sperm after coculture with epididymal epithelium Human Reproduction 11 1451-1456

Brooks DE and Higgins SJ (1980) Characterization and androgen dependence of proteins associated with luminal fluid and spermatozoa in the rat epididymis Journal of Reproduction and Fertility 59 363-375

Brown DV, Amann RP and Wagley LM (1983) Influence of rete testes fluid on the metabolism of testosterone by cultured principal cells isolated from the proximal or distal caput of the rat epididymis Biology of Reproduction $\mathbf{2 8}$ $1257-1268$

Burkett BN, Schulte BA and Spicer, SS (1987a) Histochemical evaluation of glycoconjugates in the male reproductive tract with lectin-horseradish peroxidase conjugates I. Staining of principal cells and spermatozoa in the mouse American journal of Anatomy 178 11-22

Burkett BN, Schulte BA and Spicer SS (1987b) Histochemical evaluation of glycoconjugates in the male reproductive tract with lectin-horseradish peroxidase conjugates II. Staining of ciliated cells, basal cells, flask cells and clear cells in the mouse American Journal of Anatomy 178 23-29

Byers SW, Djakiew D and Dym M (1985) Structural features of rat epididymal epithelial cells in vitro. Journal of Reproduction and Fertility 75 401-411

Byers SW, Hadley MA, Djakiew D and Dym M (1986) Growth and characterization of polarized monolayers of epididymal epithelial cells and Sertoli cells in dual environment culture chambers Journal of Andrology 7 59-68

Byers SW, Citi S, Anderson JM and Hoxter B (1992) Polarized functions and permeability properties of rat epididymal epithelial cells in vitro. Journal of Reproduction and Fertility 95 385-396

Cameo MS and Blaquier JA (1976) Androgen-controlled specific proteins in rat epididymis Journal of Endocrinology 69 47-55

Chang SM and Chung LWK (1989) Interaction between prostatic fibroblast and epithelial cells in culture: role of androgen Endocrinology 125 2719-2727

Cooke PS, Uchima FA, Fujii DK, Bern HA and Cunha GR (1986) Restoration of normal morphology and estrogen responsiveness in cultured vaginal and uterine epithelia transplanted with stroma Proceedings of the National Academy of Sciences USA 83 2109-2113

Cooke PS, Young P and Cunha GR (1991) Androgen receptor expression in developing male reproductive organs Endocrinology 128 2867-2873

Cooper TG (1986) The Epididymis. Sperm Maturation and Fertilisation P 281 Springer-Verlag, Heidelberg

Cooper TG, Yeung CH and Meyer $\mathbf{R}$ (1989) Immature rat epididymal epithelial cells grown in static primary monolayer culture on permeable supports. I. Vectorial secretion Cell and Tissue Research 256 567-572

Cooper TG, Yeung CH, Meyer R and Schulze H (1990) Maintenance of human epididymal epithelial cell function in monolayer culture Journal of Reproduction and Fertility 90 81-91

Cunha GR, Bigsby RM, Cooke PS and Sugimura Y (1985) Stromal-epithelial interactions in adult organs Cell Differentiation 17 137-148 
Djakiew D, Byers SW and Dym M (1984) Receptor-mediated endocytosis of $\alpha_{2}$-macroglobulin and transferrin in rat caput epididymal epithelial cells in vitro. Biology of Reproduction 31 1073-1085

Esponda P and Bedford JM (1986) The influence of body temperature and castration on the protein composition of fluid in the rat epididymis Journal of Reproduction and Fertility 78 505-514

Finaz C, Boue F, Meduri G and Lefevre A (1991) Characterization of rat epithelial epididymal cells purified on a discontinuous Percoll gradient Journal of Reproduction and Fertility 91 617-625

Flickinger CJ, Herr JC and Klotz KL (1988) Immunocytochemical localization of the major glycoprotein of epididymal fluid from the cauda in the epithelium of the mouse epididymis Cell and Tissue Research 251 603-610

Hamilton DW (1975) Structure and function of the epithelium lining the ductuli efferens, ductus epididymidis, and ductus deferens in the rat. In Handbook of Physiology Vol. 5 Endocrinology pp 259-301 Eds RO Greep and EB Astwood. American Physiological Society, Washington

Huang SJ, Leung AYH, Fu OW, Chung YW, Zhou TS, Chan PSF and Wong PYD (1992) Electrophysiological studies of anion secretion in cultured human epididymal cells Journal of Physiology 455 455-469

Janecki A and Steinberger A (1987) Vectorial secretion of transferrin and androgen binding protein in Sertoli cell cultures effect of extracellular matrix, peritubular myoid cells and medium composition Molecular and Cellular Endocrinology 52 125-135

Kedinger M, Simon-Assmann P, Alexandre E and Haffen K (1987) Importance of a fibroblastic support for in vitro differentiation of intestinal endodermal cells and for their response to glucocorticoids Cell Differentiation 20 171-182

Kierszenbaum AL, Lea O, Petrusz P, French FS and Tres LL (1981) Isolation, culture and immunocytochemical characterization of epididymal epithelial cells from pubertal and adult rats Proceedings of the National Academy of Sciences USA 78 1675-1679

Laemmli UK (1970) Cleavage of structural proteins during the assembly of the head of bacteriophage $T_{4}$ Nature 227 680-685

Liu H-W, Sun GH, Shy SR and Shyu HY (1992) Post-natal development and testosterone dependence of GP-83 and GP-49, two sperm maturationrelated glycoproteins in BALB/c mouse epididymis Cell and Tissue Research 269 189-194

Manin M, Veyssiere G, Cheyvialle D, Chevalier M, Lecher P and Jean C (1992) In vitro androgenic induction of a major protein in epithelial cell subcultures from mouse vas deferens Endocrinology 131 2378-2386

Martikainen P, Harkonen P, Vanhala T, Makela S, Viljanen M and Suomin J (1987) Multihormonal control of synthesis and secretion of prostatein in cultured rat ventral prostate Endocrinology 121 604-611

Moore HDM and Hartman TD (1986) In vitro development of the the fertilizing ability of hamster spermatozoa after co-culture with epithelium from the proximal cauda epididymidis Journal of Reproduction and Fertility $\mathbf{7 8} 347-352$

Moore HDM, Hartman TD and Smith CA (1986) In vitro culture of hamster epididymal epithelium and induction of sperm motility Journal of Reproduction and Fertility $\mathbf{7 8} \quad 327-336$

Moore HDM, Curry MR, Penfold LM and Pryor JP (1992) The culture of human epidydimal epithelium and in vitro maturation of epididymal spermatozoa Fertility and Sterility 58 776-783

Orgebin-Crist MC, Olson GE and Danzo BJ (1981) Factors influencing maturation of spermatozoa in the epididymis. In Intragonadal Regulation of Repro- duction pp 393-417 Eds P Franchimont and CP Channing. Academic Press, London

Orgebin-Crist MC, Davies JJ, Storey P and Olson GE (1984) Effect of D-valine and cytosine arabinoside on $\left[{ }^{3} \mathrm{H}\right]$ thymidine incorporation in rat and rabbit epididymal epithelial cell cultures In vitro $2045-52$

Orgebin-Crist MC, Hoffman LH, Olson GE and Skudlarek MD (1987) Secretion of proteins and glycoproteins by perifused rabbit corpus epididymal tubules: effect of castration American Journal of Anatomy 180 49-68

Pera I, Ivell R and Kirchhoff C (1996) Body temperature $\left(37^{\circ} \mathrm{C}\right)$ specifically down-regulates the mRNA for the major sperm surface antigen CD52 in epididymal cell culture Endocrinology 137 4451-4459

Raczek S, Yeung CH, Wagenfeld A, Hertle L, Schulze H and Cooper TG (1994) Epithelial monolayers from human epididymal and efferent duct tubules testosterone metabolism and effects of culture conditions on cell height and confluence Epithelial Cell Biology 3 126-136

Raczek S, Yeung CH, Hasilik A, Robenek H, Hertle L, Schulze H and Cooper TG (1995) Immunocytochemical localisation of some lysosomal hydrolases, their presence in luminal fluid and their directional secretion by human epididymal cells in culture $C_{e} l l$ and Tissue Research $280415-425$

Regalado F, Esponda P and Nieto A (1993) Temperature and androgens regulate the biosynthesis of secretory proteins from rabbit cauda epididymidis Molecular Reproduction and Development 36 448-453

Rundlett SE, Gordon DA and Miesfeld RL (1992) Characterization of a panel of rat ventral prostate epithelial cell lines immortalized in the presence or absence of androgens Experimental Cell Research 203 214-221

Sar M, Lubahn DB, French FS and Wilson EM (1990) Immunohistochemical localisation of the androgen receptor in rat and human tissues Endocrinology 127 3180-3186

Smith CA, Hartman TD and Moore HDM (1986) A determinant of $M_{\mathrm{r}} 34000$ expressed by hamster epididymal spermatozoa after co-culture with epithelium from the proximal cauda epididymis Journal of Reproduction and Fertility $78337-345$

Soler C, Yeung CH and Cooper TG (1994) Development of sperm motility in the murine epididymis International Journal of Andrology 17 271-278

Sun EL and Flickinger CJ (1982) Proliferative activity in the rat epididymis during postnatal development Anatomical Record 203 273-284

Swinnen K, Cailleau J, Heyns W and Verhoeven G (1990) Prostatic stromal cells and testicular peritubular cells produce similar paracrine mediators of androgen action Endocrinology 126 142-150

Tezon JG, Vazquez MH, Piñeiro L, De Larminat MA and Blaquier JA (1985) Identification of androgen-induced proteins in human epididymis Biology of Reproduction 32 584-590

Thompson EW, Blackshaw AW and Raychoudhury SS (1995) Secreted products and extracellular matrix from testicular peritubular myoid cells influence androgen-binding protein secretion by Sertoli cells in culture Journal of Andrology 16 28-35

Verhoeven G, Swinnen K, Cailleau J, Deboel L, Rombauts L and Heyns W (1992) The role of cell-cell interactions in androgen action Journal of Steroid Biochemistry 41 487-494

Yeung $\mathrm{CH}$, Cooper TG and Meyer R (1989) Immature rat epididymal epithelial cells grown in static primary monolayer culture on permeable supports. II. Histochemistry and ultrastructure Cell and Tissue Research 256 573-580 